and apologised for the rough handling. I was helped to my feet and allowed to get back into the ambulance. Remembering a face had helped to save my life.

My consultant had already arrived on the wards and had started sorting patients in triage. Five of the 20 patients admitted were placed on the danger list and needed surgery as soon as possible. I went to theatre to get cracking. Most of the gunshot injuries affected axillary and femoral neurovascular structures. We operated for the rest of the night and early morning. We were relieved by a new team and allowed to go home. I refused transport and walked home. After a shower and a quick breakfast I slept for a short while. I was fresh and ready to go back to the hospital but a state of emergency had been declared and the curfew had come into force. Therefore I could not leave home. I regarded Saturday and Sunday as looting days, and they were difficult and painful. We were hoping that the police and the military would take severe measures against people who raided public and private properties. Within a few hours after the shooting, however, we had to look after these people using already depleted human and medical resources.

The events of Monday became a waiting game. The curfew had been extended for 24 hours around the parliament and television buildings and for 18 hours for the rest of the country. The hospital had been set on red alert in anticipation of an influx of more injured people. It was rumoured that the Red House was going to be stormed commando style. Thank God it never happened as the hospital staff had started showing signs of exhaustion.

At $915 \mathrm{pm}$ a news flash over the national radio said that the prime minister had agreed to step down and that the Jamaat Al Muslimeen people taking part in the seige would be granted amnesty. This was not substantiated and never happened.

The new day did not shed any further light on the situation. If anything, it worsened. A warning from the meteorological office that an area of disturbed weather about 270 kilometres east of and approaching Trinidad at more than 50 kilometres an hour put the hospital on a double red alert. The waiting was exhausting. There were patients with non-traumatic surgical problems who could not be dealt with as this would have blocked the only functioning theatre, and there was a shortage of trained theatre staff. The hurricane changed course before hitting Trinidad. Wounded looters, however, continued to flow through in dribs and drabs.

On Wednesday, five days into the seige, news came through that the hostages had all been released unconditionally. At the time of writing 300 patients directly affected by the coup attempt had been admitted to this hospital. All had gunshot injuries, mainly to the chest and limbs. Three died on the ward and seven were dead on arrival. Over a third of the patients were allegedly injured during looting. The effects that this coup attempt will have on the already overstretched medical services have yet to be calculated.

\title{
Java 1942-5: extracts from the diary of a medical officer
}

\section{Nowell Peach}

On the outbreak of war I applied to the BMA for enlistment and was commissioned into the Royal Air Force Volunteer Reserve (Medical) as a flight lieutenant. My first attempt at the primary FRCS examination had to wait.

From September 1940 I served as a medical officer in Malaya, until it fell to Japanese forces in February 1942. The invasion was all too close-the airfield at Alor Star, where I was stationed, was directly bombed. I volunteered to stay on after the squadron had left as medical officer to the 100 personnel who remained for advanced refuelling and bomb loading [and for this he was later mentioned in dispatches]. Escaping through Singapore, a 400 mile drive away, I was then posted to Sumatra. But a month later the Japanese parachute regiments invaded.

Next stop was Java. At No 1 Allied Hospital, Bandung, I settled down at last to some surgery. The hospital, in a fine modern school, was under

\section{RH136EY}

Nowell Peach, FRCS, retired general practitioner surgeon

BrMed F 1990;301:1469-71

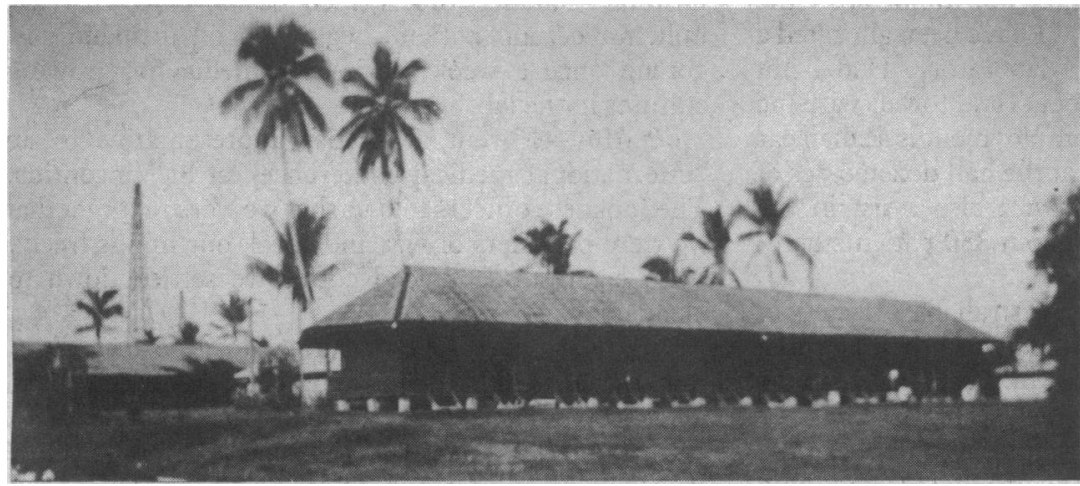

Officers' sleeping quarters, RAF Alor Star, Malaya the command of an Australian surgeon, Lieutenant Colonel E E "Weary" Dunlop. Within a week of arriving we had to deal with nearly 40 battle casualties, operating continuously for 10 hours. It was the last real surgical work that I would see for over three yearstwo days later the Netherlands East Indies capitulated, the hospital was closed, and I became a prisoner of war.

Over the next year I was moved six times. Conditions in the camps varied. The first was awful, an old local jail in which the covered enclosure that was provided for the British measured only about 30 by 60 yards. Some 50 of the 500 men had to sleep outside and on their first night their temporary bivouacs were flooded out by rain. There were two barely functioning showers and 10 latrines, which had to be unblocked by the prisoners. The diet was poor-rice pap twice a day and vegetable stew at night. Most of the men had polyuria and postural hypotension but there were no serious illnesses in the six weeks that I spent there. Later, the telltale signs of vitamin deficiency appeared - men would lie with their feet in water to reduce the burning sensations. The only source of protein at one of the camps were the maggots that, despite repeated washing, clung to the rice.

At last, in April 1943, I was moved to a new hospital and was able to get down to work again. The following is an account from my diary at the time.

\section{Mater Dolorosa Convent, Batavia (now Djakarta),} Java

13 April-In charge of five medical officers and 30 orderlies I moved from Tandjong Priok POW camp to Mater Dolorosa Convent, Batavia. The modern (1931) buildings, with tiled floors and proper sanitation, will be POW Hospital No 2 for Infectious Diseases. 


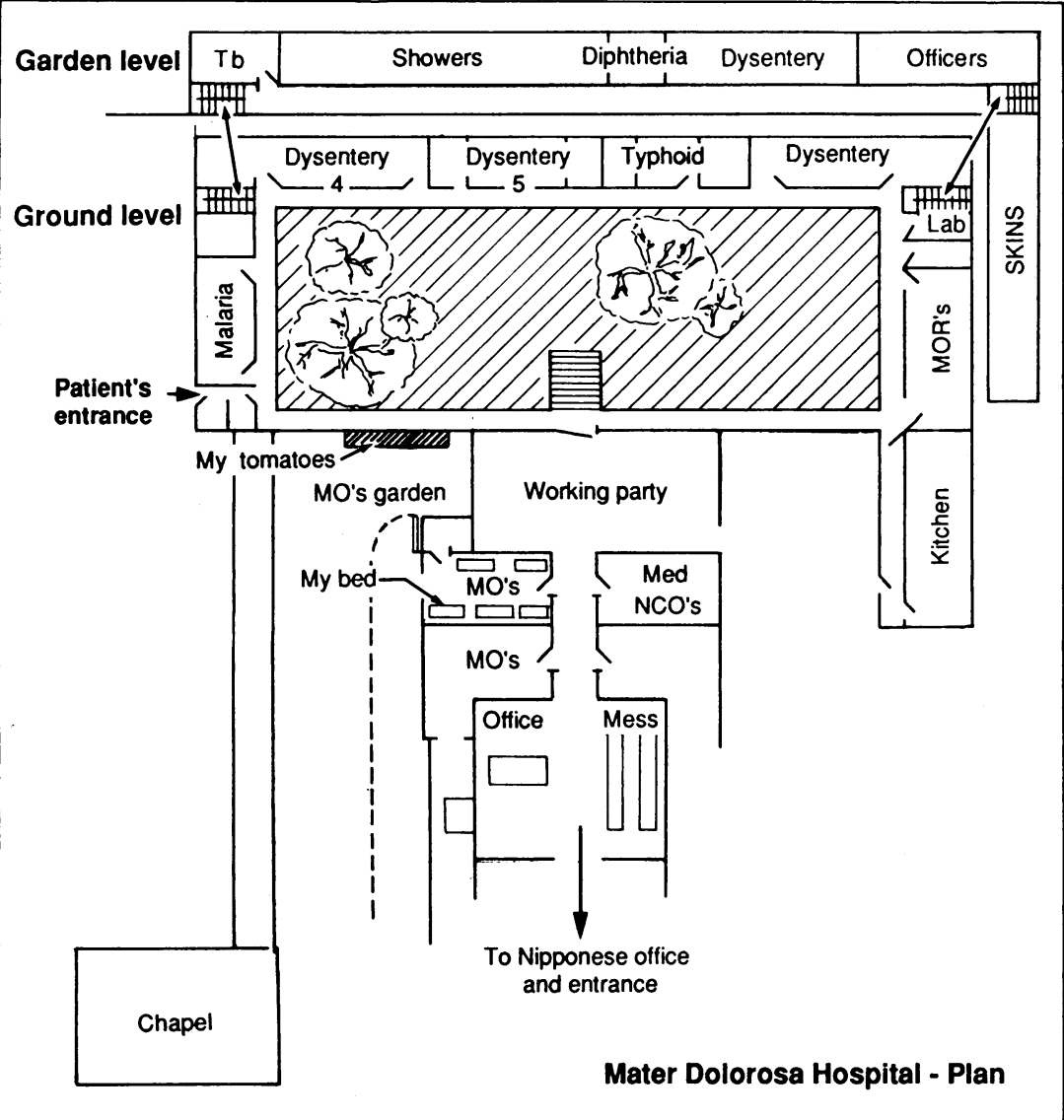

Plan of Mater Dolorosa Hospital, Batavia
17 April-The new hospital opened. About 180 sick men arrived from Tandjong Priok. They are all sitting cases except one with a tuberculous hip whom I had previously put up in a Thomas's splint and sliding bed specially made by Royal Engineer staff in camp. The Japanese guard in charge of hospital administration says that the bed frame has not been signed for and must go back to Priok.

18 April-Lying patients arrived from the old POW hospital. Those with tuberculosis were put in the same ward as Gunner Webb, the man with the tuberculous hip, and we could not get the Japanese corporal to understand that he is not infectious and should be moved. They seem to be scared stiff of tuberculosiseven the guards on the hospital transport lorries were wearing masks.

20 April-Four British medical officers and all the orderlies moved to the new main POW hospital at St Vincentius Convent. Nine medical officers now remain - seven of whom are Dutch-covering tuberculosis, typhoid, dysentery, malaria, ENT, skins, pathology, and surgery.

10 May-I am in charge of surgical cases but it is nothing much of a job. I had hoped to gain a little experience but apparently I was included on the staff only to diagnose, rather than treat, any surgical conditions that might arise here. For minor ops - the occasional abscess or excision - I have been allocated a corner of the small pathology laboratory. Had I not brought a modicum of instruments and towels with me I would have none. My main employment is a small ear clinic at 11 o'clock where I treat the half dozen cases of otitis externa that present daily. I also assist in the malaria ward. There are now about 350 patients here, with the following diagnoses:

Malaria: about 40, mostly Australians infected in Timor, have had 30-40 relapses between them in three week cycles. They are given one of three treatmentsquinine only ( $1 \mathrm{~g}$ daily for five days), ateprin only (five days), or quinine followed by plasmoquine. $\mathrm{Dr}$ de Graaf hopes to confirm his suspicions that plasmoquine does not prevent relapse.

Skins: 60 patients. For the first month scabies was the scourge here. Widespread in the old hospital but often overlooked, it has now been controlled with the help of some sulphur and some education (constant mention of its name to the men). Good progress has been made with all the skin cases - probably because their work in the ward's garden is mutually beneficial to their plants and their skins.

Dysentery: the patients, about 150 in total, are spread among four wards according to the severity of their illness. These wards and that for tuberculosis have seen most of the deaths in the hospital so far.

Tuberculosis: there were about 10 cases of pulmonary tuberculosis, all showing positive sputum. Three died in the first month here. These poor fellows have been put in a ward where the ventilation is inadequate - the windows are all up near the ceiling. For over a month these windows have had to be closed at night and the Japanese have only recently been persuaded that they should be left open.

For the first two weeks the Japanese gave us no extra food and the supply of medicines was poor. However, at the beginning of May they started supplying about 100 hens' eggs, 180 bananas, and 20 papayas daily. Quite a good supply of drugs was received from St Vincentius dispensary. There are still no general facilities for $x$ rays (except the limited capability of a dental unit) and no Wasserman, Widal, etc.

During the month our own living conditions have much improved, with beds and mattresses for the officers and metal frames with boards for the ordinary ranks. Butter and bread have also arrived.

The commandant of this hospital is mild and gentlemanly. I have never seen him lose his temper in the presence of a prisoner of war. He is not soft, however-I once glimpsed him slapping one of his soldiers repeatedly on both sides of his face (slapping seems to be a recognised disciplinary measure). The guards seem reasonably well disposed towards us. The guard commander-only a youngster, about 20 -is very keen to learn English and sometimes comes into our room to talk. He is most polite. He called Captain Dowdall a very old man, like his father, and said that he loved him!

One of our greatest difficulties and annoyances is that the administration of the hospital is dominated by a Japanese corporal who appears to have scanty medical knowledge. He is petty about certain small regulations. For instance, he ordered that a patient's radiant heat be removed because there is a rule that electric light bulbs may not be used without permission and he had not been asked. I have also heard him raging away in the office about filling in forms that he does not understand.

Hospital funds come from three sources: officers' subscriptions (fl 1.50 per month), canteen profits, and subscriptions from camps. In May the officers also bought $3 \mathrm{~kg}$ of liver daily for especially sick patients. With the general funds we bought extras for the whole hospital-katjang idjoe (green beans) twice a week, milk for certain patients, eggs and oil to make nasi goreng once a week, and yeast media for growing cultures in the lab.

30 May-I went as British representative to an "international medical conference" at St Vincentius. The Japanese officers told us that we were to forget that we were prisoners of war and speak our minds freely. With cigarettes and iced coffee we settled down to business.

Firstly, we were told that the Japanese authorities were concerned that there were many sick men among the prisoners, and we were asked what was needed to make them fit. We said that we needed more protein, especially meat, and more vitamins, in the form of red 
unpolished rice rather than the polished rice we had had so far. We also requested that letters be allowed through (not one had arrived at the hospital, although we had heard that about 20000 were held up in Batavia) and that books, dentures, glasses, and exercise facilities be provided.

The Japanese announced that they intended to return the POWs fit and well and that, subject to general shortages in Java, they would do what they could to supply better food. But no promises were made and it remains to be seen if anything will happen.

\section{Afterwards}

I stayed at Mater Dolorosa for just over one year. Between May 1944 and April 1945 I was moved twice more, ending up at the old jail where I had first been imprisoned. It was now grossly overcrowded, 3000 men (British, Australian, and Dutch) having a space of some 80 by $200 \mathrm{~cm}$ for each man. But there was some comfort-Red Cross parcels (the first we had seen) arrived with bully beef. And it was here that we finally heard that the war had ended on 24 August. I waited a month, assisting in the evacuation of British and Dutch patients, before flying to Singapore to sail home. Even then, I had an uncomfortable half an hour while the Dakota aeroplane almost had to turn back because of bad weather.

Within six months of arriving home I passed the primary fellowship. The American copy of Gray's Anatomy, given to me by Weary Dunlop, had stood me in good stead.

\title{
Deception by immunisation, revisited
}

\author{
John D C Bennett, Lydia Tyszczuk
}

An article published in American Society of Microbiology News was brought to wider attention by a $B M \mathcal{F}$ editorial entitled "Deception by immunisation." 2 The authors described how they used an artificial false positive Weil-Felix reaction to deceive the occupying Nazi forces into thinking their Polish village was endemic for typhus. This spared the villagers from being deported to slave labour camps. The editorial urged that two questions which arose be explored further: that the artifically induced antibody titre remains constant rather than varying as in the disease, and that the mortality of typhus is considerable. How then were the thorough, methodical occupying Nazi forces outwitted? We attempted to unravel the mystery.

\section{Historical background}

The appeasement of Hitler by the allies came to an end with his invasion of Poland on 1 September 1939, which precipitated the second world war. His three Panzer (armoured) corps made swift work of the Polish defences, and Warsaw, which was ruthlessly bombed, was reached within a week. The real objective of the attack, however, lay 120 miles further east at Brest-Litovsk, where the northern and southern corps linked in a giant pincer movement, enveloping the capital and ensuring the collapse of Poland. There was little doubt as to Hitler's plans, which he had alluded to in a speech to his generals on 23 May 1939 and which were quickly put into effect: "Danzig is not by any means the main cause of the disagreement. The chief objective is to get new areas for Germany in the east and to control and safeguard new sources of food stuffs." A reign of terror ensued, resulting in the deaths of five and a half million Poles and mass deportation to labour camps. Here a total of 500000 to 600000 slaves were sent to work in the factories of the Reich and the occupied countries. ${ }^{3}$

\section{Typhus fever}

In $1910 \mathrm{~W}$ James Wilson stated that typhus fever was "a disease which modern sanitary reform has banished from the midst of progressive communities." It had not been recognised as separate from typhoid fever until the 1840 s or ' $50 \mathrm{~s}$, and often it was impossible to make a distinction clinically. It was often separated from typhoid fever and classified with the acute exanthemata, which it resembles in its infectivity, onset, and rash, but "on the other hand it differs entirely from these in that it is always associated with unhygienic conditions." 4 The view that contagion of typhus is conveyed by fleas was advocated on epidemiological grounds by Hay in $1907 . .^{5}$ In 1910 Ricketts and Wilder showed that the infecting agent was present in the blood and that insects, probably Pediculi vestimenti, were the agents carrying infection. ${ }^{6}$

It is useful to consider some work done by two military microbiologists who have not received the recognition by history that perhaps they are due. The first was W James Wilson, who served with the Royal Army Medical Corps in France during the first world war. From there he wrote a very mild letter to the $B M F^{7}$ acknowledging the fact that the Germans were testing the blood of suspected victims of typhoid fever with the Weil-Felix reaction, which had been described in 1916. He drew attention to the fact that he had described this reaction in 1910 , at which time he said: "Results definitely prove that in typhus fever agglutinins for the typho-coli group of micro-organisms are present in the blood serum of the patients. The knowledge recently acquired regarding the presence of heterologous agglutinins in cerebrospinal fever prevents us from drawing the unwarranted conclusion that the presence of a bacillus in the intestine and urine and the discovery of an agglutinin for it in the blood indicate that such an organism is the cause of the disease in question." 4 The Weil-Felix reaction takes advantage of the fact that certain proteus organisms share a common antigen with the rickettsias. Antibodies that agglutinate proteus $\mathrm{Ox}-19$ are found in the serum of patients suffering from typhus borne by the European louse.

The second doctor, Rudolf Weigl, was four times a candidate for a Nobel Prize $(1932,1936,1942,1946)$. $\mathrm{He}$ worked in military bacteriological laboratories in Krakow and Przemysl during the years 1916-9, when many cases of typhus occurred among the prisoners of war. He cultivated a rickettsia suspension in the louse gastrointestinal tract (with the aid of a capillary tube through the louse's anus) and managed in 1924 to make a vaccine. This did not produce immunity but ensured that the disease would take a mild course. It was successfully used in various parts of the world where typhus was endemic, and it was estimated that eight million people were vaccinated in Poland and Russia during the $1930 \mathrm{~s} .{ }^{8} \mathrm{He}$ also proved that dead dried lice were infective and louse excreta remained infective for many months. Hence to control an epidemic not only vaccination but disinfection was needed. 